\title{
Road-killed toads as a non-invasive source to study feeding ecology of migrating population
}

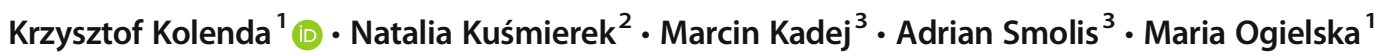

Received: 5 July 2018 / Revised: 15 April 2019 / Accepted: 27 May 2019 /Published online: 17 June 2019

(C) The Author(s) 2019

\begin{abstract}
Little is known about amphibian feeding activity during post-hibernation migration to breeding ponds. It is widely assumed that explosively breeding anurans do not feed between the end of hibernation and completion of breeding. We investigated the potential for using road-killed common toads Bufo bufo in order to find out whether migrating toads feed during this period and to assess the content of their stomachs. We collected a total of 416 toad carcasses during spring migration from two study sites in south-western Poland, of which 246 (59\%) carcasses contained intact digestive tracts (stomach and intestines). In 97 of these (39\%), we found stomach contents composed of invertebrate remains, whereas the intestines of $180(73 \%)$ toads contained already-digested animal remains. We found no significant differences between males and females, with or without prey, or between individuals at two different study sites. We found a total of 290 prey items, classified to the lowest possible taxonomic rank. Formicidae (Insecta: Hymenoptera) was the most abundant taxon; however, based on the dominance index, common toads could not be classified as fully polyphagous. The Jaccard and Bray-Curtis indices showed a generally low level of intersexual similarity in diet composition at both study sites as well as between males and females. Our results show that road-killed toads can be used to study foraging activity and diet composition; however, this approach should be tested on more species.
\end{abstract}

Keywords Bufo bufo $\cdot$ Common toad $\cdot$ Diet $\cdot$ Feeding ecology $\cdot$ Road mortality $\cdot$ Migration $\cdot$ Poland

\section{Introduction}

Amphibians are important predators in aquatic and terrestrial habitats (Davic and Welsh 2004; Whiles et al. 2006; Hocking and Babbitt 2014). The composition of their diets, determined

This article is part of the Topical Collection on Road Ecology Guest Editor: Marcello D'Amico

Electronic supplementary material The online version of this article (https://doi.org/10.1007/s10344-019-1292-4) contains supplementary material, which is available to authorized users.

Krzysztof Kolenda

krzysztof.kolenda@uwr.edu.pl

1 Amphibian Biology Group, Department of Evolutionary Biology and Conservation of Vertebrates, Institute of Environmental Biology, University of Wrocław, Sienkiewicza 21, 50-335 Wrocław, Poland

2 Department of Parasitology, Institute of Genetics and Microbiology, Wrocław University, Przybyszewskiego 63, 51-148 Wrocław, Poland

3 Department of Invertebrate Biology, Evolution and Conservation, Institute of Environmental Biology, University of Wrocław, Przybyszewskiego 65, 51-148 Wrocław, Poland by the occurrence of prey species (mostly invertebrates) in their foraging habitat (Guidali et al. 2000), is a good indicator of the habitat's condition (Gunzburger 1999). Although diet composition has been examined and seasonal variation in components observed in many amphibians (e.g. Cogălniceanu et al. 2000; Aszalos et al. 2005; Kovács et al. 2007; Vignoli and Luiselli 2012; Pesarakloo et al. 2017), little is known about their feeding activity during pre-spawning migration.

Species with prolonged breeding seasons, such as newts (e.g. the smooth newt Lissotriton vulgaris and the alpine newt Ichthyosaura alpestris) and anurans (e.g. the tree frog Hyla arborea and water frogs Pelophylax spp.), commence feeding at the beginning of the post-hibernation life stage (Kovács et al. 2007; Guidali et al. 2000; Kopecký et al. 2016). This stage includes feeding during the spring migration to breeding ponds and aquatic breeding period. However, there is a common belief that explosive breeders, i.e. amphibians characterised by short and rapid breeding activity (e.g. the common frog Rana temporaria and toads Bufo spp.), do not feed until after the conclusion of spawning. Specifically, they abstain from feeding during the short interval between their emergence from hibernation sites and the end of the breeding 
season. Although this assumption is common in the literature, it is not supported by empirical data (Tinsley 1990; Bókony et al. 2018), and at best refers to anecdotal observations (Tinsley and Jackson 1988) or studies concerning the aquatic period immediately before or during spawning (Jørgensen et al. 1978). In fact, only Gittins (1987), based on one population in Wales, showed that $97 \%$ of all toads did not feed before entering the breeding pond, whereas other authors have omitted post-hibernation terrestrial migration and have focused only on individuals caught in breeding ponds (Heusser 1968; Guidali et al. 2000). Consequently, this has led to the transmission of misleading information.

The common toad Bufo bufo is an example of a widely studied, explosively breeding amphibian. It belongs to the $B$. bufo species group, which is widespread in most of Europe, northern Eurasia, and north Africa, inhabiting various habitats up to $3000 \mathrm{~m}$ a.s.l. (Agasyan et al. 2009; Arntzen et al. 2013). The diet of this important predator of invertebrates, including the tadpole stage, metamorphs, and sexual maturity, has been widely studied as well (Diaz-Paniagua 1989; Crnobrnja-Isailović et al. 2012 and references therein; Čađenović et al. 2018).

Common toads are also one of the most frequent traffic victims among amphibians in Europe (Elzanowski et al. 2009; Beebee 2013). Their carcasses may constitute useful material for various non-invasive studies (Martel et al. 2012; Kaczmarski et al. 2016). It was recently proven that toads are killed on roads irrespective of their individual ages and therefore constitute a representative sample of a migrating population (Kolenda et al. 2019).

In this study, we assessed the possibility of using roadkilled common toads to determine the content of their stomachs and intestines and to find out whether migrating toads feed and whether their foraging activity depends on sex or habitat type.

\section{Materials and methods}

\section{Material collection}

The study was conducted at two different sites located in south-western Poland: (i) a suburb of Wrocław $\left(51^{\circ} 10^{\prime}\right.$ $22.98^{\prime \prime} \mathrm{N}, 16^{\circ} 50^{\prime} 29.93^{\prime \prime} \mathrm{E}, 128 \mathrm{~m}$ a.s.l.), comprising a primarily forested area with a housing estate and ponds, and (ii) Złoty Las (50 $46^{\prime} 46.36^{\prime \prime} \mathrm{N}, 16^{\circ} 24^{\prime} 55.38^{\prime \prime}$ E, $337 \mathrm{~m}$ a.s.1.), situated in forested foothills near the Złotnica River.

Road-killed toads were collected during their nocturnal migration to breeding ponds between the end of March and beginning of April in 2017 and 2018. Toad carcasses were found on roads located at most $50 \mathrm{~m}$ from ponds; thus, the migrating adults died just before entering the water. We collected only recently killed individuals within a few hours of death, and did not include flattened or desiccated carcasses. Each toad carcass was placed in a plastic ziplock bag, transported to the lab, and frozen within a maximum of $3 \mathrm{~h}$ after collection (Caldwell 1996; Solé et al. 2005). The sex of individuals was determined according to visual sexual characters and gonads (Kaczmarski et al. 2016). The stomachs and intestines were dissected in Petri dishes and their contents analysed by means of a stereomicroscope. The prey items were identified to the lowest possible taxonomic rank, depending on degree of decomposition. Besides animal prey, the presence of plant material and/or sand grains was noted. In the case of intestinal contents, we noted only the presence or absence of digested food remains.

\section{Statistical analyses}

We used $2 \times 2$ contingency tables and Fisher's exact tests to compare (i) the proportion of males and females with stomach contents at the two study sites and (ii) the proportion of individuals with stomach and intestinal contents at the two study sites. We also compared the mean prey number caught by males and females at both localities using the MannWhitney $U$ test. A statistical significance level of $p<0.01$ was defined in order to avoid type I error due to multiple comparisons.

We estimated the diversity of diet composition using the Shannon-Wiener $(H)$ index and determined the level of food specialisation using the Berger-Parker dominance index. Intersexual and interpopulational similarities in terms of diet composition were compared using the Jaccard and BrayCurtis indices. Except for the $H$ index, all indices were calculated for 14 taxonomical groups which covered the classifications of all prey (see Supplementary Table 1 for details). Statistical analyses were performed using Statistica 13.1 software (StatSoft, Poland); diversity indices were calculated using BioDiversity Pro 2.0.

\section{Results}

In total, we collected 416 common toads: 178 in Wrocław and 238 in Złoty Las. Among them, 246 (59\%) individuals were characterised by intact digestive tracts (stomach and intestine); only these toads were included in the subsequent analysis (Table 1). In 97 (39\%) individuals, we found stomach contents composed of invertebrate remains (Table 1). There were no significant differences between males and females, with or without prey, in Wrocław (Fisher's exact test, $p=1$ ) and Złoty Las $(p=0.83)$, or between individuals, with or without prey, between study sites $(p=0.89)$ (Table 1). Of the total of 246 toads with intact digestive tracts, we found intestinal contents in $180(73 \%)$, with significant differences in their proportion between study sites (Fisher's exact test, $p=0.006$ ). We found no content in the intestines of only 4 (4.1\%) toads with 
Table 1 Number of the roadkilled common toads Bufo bufo used in this study

\begin{tabular}{|c|c|c|c|c|c|c|c|}
\hline \multirow[t]{2}{*}{ No. of toads } & \multicolumn{3}{|c|}{ Wrocław } & \multicolumn{3}{|c|}{ Złoty Las } & \multirow[t]{2}{*}{ Total } \\
\hline & Male & Female & Total & Male & Female & Total & \\
\hline All collected & 132 & 46 & 178 & 174 & 64 & 238 & 416 \\
\hline With digestive tract preserved & 98 & 25 & 123 & 93 & 30 & 123 & 246 \\
\hline With prey remains in stomach & 40 & 9 & 49 & 37 & 11 & 48 & 97 \\
\hline With intestinal content & 65 & 15 & 80 & 79 & 21 & 100 & 180 \\
\hline With non-prey items: plant remains & 16 & 5 & 21 & 11 & 4 & 15 & 36 \\
\hline Soil grains & 10 & 0 & 10 & 3 & 3 & 6 & 16 \\
\hline
\end{tabular}

prey in the stomach. In $36(15 \%)$ and $16(6.5 \%)$ toads, we found plant remains or soil grains, respectively (Table 1); we found intestinal contents in all of these toads but found animal remains in the stomachs of only $23(64 \%)$ and $9(25 \%)$, respectively (Table 1).

Among 97 toads with stomach contents, 22 cases included animal remains which had been digested to the extent that it was impossible to count the prey items or identify them to a low taxonomic rank; thus, these cases were excluded from the analysis. In total, we found 290 prey items classified to 57 taxa and grouped into 14 higher taxonomic ranks (see Table 2 and supplementary Table S1 for details). Members of the Formicidae (Insecta: Hymenoptera) family constituted the most abundant prey at both study sites (77\% in Wroclaw and $32 \%$ in Złoty Las), followed by beetles (Insecta: Coleoptera, 8.9\%) and spiders (Arachnida,7.7\%) in Wrocław, and spiders (Arachnida, 11.8\%), millipedes (Myriapoda: Julidae, 11\%), isopods (Crustacea: Isopoda, $10 \%$ ), earwigs (Insecta: Dermaptera, 10\%), true bugs (Insecta: Hemiptera, 9.3\%), and beetles (Insecta: Coleoptera, $8.5 \%$ ) in Złoty Las. Other taxonomic groups were represented by less than $3 \%$ of individuals (Table 2). Except for two freshwater taxa, Velia sp. (Insecta: Hemiptera) and Anacaena lutescens (Insecta: Coleoptera), others were typically terrestrial.

In Wrocław, females and males consumed $7.6( \pm 7.2)$ and $4.37( \pm 4.2)$ prey items per individual, respectively; in Złoty Las, $3.33( \pm 2.4)$ and $2.94( \pm 2.8)$, respectively, and we found no intersexual differences in numbers of caught prey (MannWhitney $U$ test, Wrocław: $Z=-0.99, p=0.32$; Złoty Las: $Z=$ $0.62, p=0.54$ ) (Table 3). In Wrocław, the diversity of the diet of males was greater than that of females (Shannon-Wiener index, $H=2.60$ vs $H=1.48$, respectively), but this trend was not observed in Złoty Las (males: $H=2.61$, females: $H=$ 2.65). The dominance index was higher in Wrocław (males: $d=0.7$, females: $d=0.9$ ) than in Złoty Las (males: $d=0.4$, females: $d=0.3$ ). Both the Jaccard and Bray-Curtis indices showed a low level of intersexual similarity in diet composition in Wrocław (0.38 and 0.45 , respectively) and Złoty Las (Bray-Curtis index, 0.4; the Jaccard index was an exception at $0.75)$. Additionally, a low level of congruence was noted in food composition between males (Jaccard index, 0.46; BrayCurtis index, 0.54$)$ and females $(0.33$ and 0.17 , respectively) at the two sites.

\section{Discussion}

Nearly $60 \%$ of all collected toads were characterised by wellpreserved digestive tracts suitable for inclusion in analysis of stomach contents. The persistence of amphibian carcasses on roads depends on many factors, such as size and body mass, rate of removal by scavengers, weather, and traffic intensity. For these reasons, over $50 \%$ of dead amphibians disappear from roads within the first $24 \mathrm{~h}$ following killed on roads (Santos et al. 2011). Thus, carcasses must be collected as soon

Table 2 Number and percentage share of particular prey items found in the stomachs of road-killed common toads Bufo bufo from Wrocław and Złoty Las

\begin{tabular}{|c|c|c|c|c|c|c|c|c|}
\hline \multirow[t]{3}{*}{ Prey categories } & \multicolumn{4}{|c|}{ Wrocław } & \multicolumn{4}{|c|}{ Złoty Las } \\
\hline & \multicolumn{2}{|c|}{ Male } & \multicolumn{2}{|c|}{ Female } & \multicolumn{2}{|c|}{ Male } & \multicolumn{2}{|c|}{ Female } \\
\hline & $N$ & $\%$ & $N$ & $\%$ & $N$ & $\%$ & $N$ & $\%$ \\
\hline Annelida & 1 & $0.76 \%$ & 0 & $0.00 \%$ & 0 & $0.00 \%$ & 0 & $0.00 \%$ \\
\hline Arachnida & 12 & $9.16 \%$ & 1 & $2.63 \%$ & 10 & $10.99 \%$ & 4 & $13.33 \%$ \\
\hline Chilopoda & 0 & $0.00 \%$ & 0 & $0.00 \%$ & 3 & $3.30 \%$ & 0 & $0.00 \%$ \\
\hline Julidae & 3 & $2.30 \%$ & 0 & $0.00 \%$ & 4 & $4.39 \%$ & 9 & $30.00 \%$ \\
\hline Isopoda & 0 & $0.00 \%$ & 0 & $0.00 \%$ & 7 & $7.69 \%$ & 5 & $16.67 \%$ \\
\hline Colembolla & 0 & $0.00 \%$ & 0 & $0.00 \%$ & 1 & $1.10 \%$ & 0 & $0.00 \%$ \\
\hline Hemiptera & 4 & $3.05 \%$ & 0 & $0.00 \%$ & 10 & $10.99 \%$ & 2 & $6.67 \%$ \\
\hline Dermaptera & 1 & $0.76 \%$ & 0 & $0.00 \%$ & 11 & $12.09 \%$ & 1 & $3.33 \%$ \\
\hline Diptera & 0 & $0.00 \%$ & 0 & $0.00 \%$ & 1 & $1.10 \%$ & 1 & $3.33 \%$ \\
\hline Coleoptera & 12 & $9.16 \%$ & 3 & $7.89 \%$ & 5 & $5.49 \%$ & 5 & $16.67 \%$ \\
\hline Formicidae & 97 & $74.05 \%$ & 34 & $89.48 \%$ & 38 & $41.76 \%$ & 2 & $6.67 \%$ \\
\hline Lepidoptera & 1 & $0.76 \%$ & 0 & $0.00 \%$ & 0 & $0.00 \%$ & 0 & $0.00 \%$ \\
\hline Plecoptera & 0 & $0.00 \%$ & 0 & $0.00 \%$ & 1 & $1.10 \%$ & 0 & $0.00 \%$ \\
\hline Gastropoda & 0 & $0.00 \%$ & 0 & $0.00 \%$ & 0 & $0.00 \%$ & 1 & $3.33 \%$ \\
\hline$\sum$ & 131 & & 38 & & 91 & & 30 & \\
\hline
\end{tabular}


Table 3 Total, mean, median, and range of prey items consumed by common toads Bufo bufo

\begin{tabular}{|c|c|c|c|c|}
\hline & \multicolumn{2}{|l|}{ Wrocław } & \multicolumn{2}{|l|}{ Złoty Las } \\
\hline & $\begin{array}{l}\text { Males } \\
(N=30)\end{array}$ & $\begin{array}{l}\text { Females } \\
(N=5)\end{array}$ & $\begin{array}{l}\text { Males } \\
(N=31)\end{array}$ & $\begin{array}{l}\text { Females } \\
(N=9)\end{array}$ \\
\hline Total number of prey items in stomach & 131 & 38 & 91 & 30 \\
\hline Mean $( \pm \mathrm{SD})$ & $4.37( \pm 4.2)$ & $7.6( \pm 7.2)$ & $2.94( \pm 2.8)$ & $3.33( \pm 2.4)$ \\
\hline Median & 3 & 5 & 2 & 3 \\
\hline Range (min-max) & $1-22$ & $2-19$ & $1-15$ & $1-8$ \\
\hline
\end{tabular}

as possible e.g. during spring evenings, the peak of activity of many species (Mazerolle 2004). Toads, being relatively large amphibians with tough skin, are a good source for various ecological studies based on road kills, in contrast to small and/or thin-skinned species, such as fire-bellied toads or newts, which are more vulnerable to damage from being run over by a car (Hels and Buchwald 2001). Moreover, particular species show various degrees of exposure to road impacts; this may depend on species mobility, ecological requirements, reproductive mode, response to traffic noise, etc. (ColinoRabanal and Lizana 2012; Tennessen et al. 2014; Grace et al. 2017). Thus, our approach may not be appropriate for all species. Although carcasses are most numerous during seasonal migration, mainly in the pre-spawning period (Orłowski 2007; Orłowski et al. 2008), our approach can be used throughout the active season; however, this may be limited by weather and the location of roads within amphibian habitats. Thus, our approach is certainly suitable for studies of the feeding ecology of explosively breeding species and may serve as a useful tool to fill gaps in knowledge about the foraging activity of such species during this particular period of life (for further discussion on using road-kill to scientific purposes, see Kolenda et al. 2019).

\section{Foraging activity during spring migration}

Although we found prey in the stomachs of only $39 \%$ of the collected toads, intestinal contents were present in $73 \%$. As amphibians are capable of processing food during hibernation (Gossling et al. 1980; Jiang and Claussen 1993), we concluded that the intestinal contents were the remnants of recently consumed food, i.e. eaten after hibernation but before breeding. Thus, the actual percentage of individuals that feed during migration may be much higher than that calculated on the basis of stomach analysis only (Gittins 1987).

We also found a relatively large share of toads with nonprey items in their stomachs. A recent study confirmed that non-prey items are most often consumed in spring (Kopecký et al. 2011). This phenomenon is probably related to accidental consumption along with animal prey, or to inefficient hunting (Dolmen and Koksvik 1983; Kovács et al. 2007). The latter factor may be explained by the lower level of prey availability following winter, but also may be connected with toads' poor body condition, which may contribute to attack responses towards items resembling prey (see also Kopecký et al. 2011). This assumption is supported by our observation of several individuals with non-prey items and no animal remains in their stomachs.

One factor negatively affecting the condition of posthibernating toads is climate change, with a trend towards milder winters and warmer early springs (Reading and Clarke 1995; Tomašević et al. 2007). Indeed, Tryjanowski et al. (2003) found a trend towards earlier breeding in common toads over a span of 25 years in Poland as a possible consequence of climate change. It is possible that higher metabolism rate and increase in utilisation of energy reserves during winter caused by higher temperatures may force toads to feed during the post-hibernation period. Thus, the almost total lack of foraging behaviour in the toads studied by Gittins (1987) may simply reflect their superior condition, possibly associated with the lack of any influence of climate change or other factors (e.g. better foraging opportunities). However, these issues require further long-term study.

Our results may warrant careful interpretation of previously published data and may also help in the design of further studies. For instance, Bókony et al. (2018) estimated female fecundity based on differences in mass between pre- and postspawning toads, and emphasised that post-hibernating individuals did not feed prior to spawning. As the toads were caught at the beginning of their breeding season (Bókony et al. 2018), they could be unable to defecate (i.e. they did not have enough time to do so, if recently fed). Although swallowed food usually stays in the stomach up to $24 \mathrm{~h}$, at colder temperatures, this period may be extended to as many as 12 days (Gossling et al. 1980). It is noteworthy that toads, and amphibians in general, are gluttonous; a toad is capable of eating a meal equalling approximately $4-5 \%$ or even $20 \%$ of its body mass (Karg and Mazur 1969; Secor and Faulkner 2002). Thus, in studies in which post-hibernating toads are used to estimate fecundity or body condition indices, authors should consider employing a stomach-flushing method prior to measurements to be sure that there are no stomach contents that could potentially bias the mass estimates. 


\section{Food composition of common toads}

Identification of prey items was possible in the case of invertebrates with highly chitinised cuticles, such as beetles, true bugs, crustaceans, centipedes, and millipedes. Greater difficulties in the determination of lower taxonomic ranks were present in the case of the soft invertebrate bodies of arachnids, stoneflies, or flies.

Our study confirmed that, during spring migration, common toads hunt diverse prey, the vast majority of which comprise epigeic forms such as millipedes (Myriapoda: Diplopoda), centipedes (Myriapoda: Chilopoda), woodlice (Crustacea: Isopoda), and various orders of insects including ants (Hymenoptera: Formicidae), earwigs (Dermaptera), beetles (families: Carabidae, Curculionidae, Coccinellidae), true bugs (Hemiptera), and caterpillars (i.e. butterfly larvae). These results correspond to other studies from many different habitats (e.g. Mollov and Boyadzhiev 2009; Crnobrnja-Isailović et al. 2012; Čađenović et al. 2018). Most prey possess venom glands in their forcipules (Chilopoda) or chelicerae (Arachnida), or produce defensive and toxic secretions (Diplopoda, Coccinellidae, Formicidae). A large share of toxic prey items in the diet confirms that toads are resistant to high levels of toxins (Smith 1951).

Based on the dominance index, common toads cannot be classified as fully polyphagous. The most abundant prey items, especially in Wrocław, were ants (Formicidae). At this locality, both sexes may be considered myrmecophagous specialists (Vences et al. 1998; Isacch and Barg 2002); however, some studies suggest only a seasonal preference for ants (Mollov and Boyadzhiev 2009). We identified a total of 13 ant species belonging to 6 genera. Interestingly, all were characterised by thin skeletons and were incapable of stinging, and in addition manifested generally weak territorial behaviour. At present, however, it is hard to assess whether this was a targeted feeding strategy or an accidental choice.

In the prey of both populations, numbers of Coleoptera were surprisingly low, while those of Arachnida were relatively high. Differences in food composition, as well as the abundance of particular prey taxa in comparison with other studies (e.g. Gittins 1987; Mollov and Stojanova 2010; CrnobrnjaIsailović et al. 2012; Čađenović et al. 2018), result primarily from seasonal changes in prey diversity (Gittins 1987; Kovács et al. 2007). However, other factors, such as habitat type, prey availability, the presence of competitors, and body size, influence amphibian diets (Houston 1973; Gittins 1987; Denton and Beebee 1994; Isacch and Barg 2002; CrnobrnjaIsailović et al. 2012). Similarly, differences in the shares of taxa preyed upon in the two populations we studied may be explained by different habitat types; however, the low level of congruence in food composition between the sexes, as well as the greater mean number of prey items consumed by females, was probably the effect of a small sample size.
In conclusion, we would like to emphasise that the potential for analysing the stomach contents of amphibian carcasses opens up a new approach for non-invasive studies on foraging activity and food composition. Moreover, since diet composition reflects prey availability and since amphibians are opportunistic feeders, studies of the digestive tract in different seasons may serve as an additional source of data on invertebrate occurrence (similar to that involving pellets in birds of prey). Indeed, we found few rare and protected species (e.g. Formica pratensis). However, it is important to note that particular amphibian species tend to be killed on roads at different levels of frequency depending on habitat type, species activity pattern, population size, etc.; moreover, depending on features of body construction, carcasses of different species tend to be found in a variety of conditions after being run over by vehicles. Accordingly, this approach should be tested on more species.

Acknowledgements We especially thank Dr. hab. Maciej Pabijan (Jagiellonian Univeristy, Poland) for helpful suggestions that greatly improved the manuscript. Also, special thanks for help with confirmation or species identification go to Dr. Sebastian Salata (Wrocław, Poland) for Formicidae, Andrzej Melke (Kalisz, Poland) for Staphylinidae, Dr. Mieczysław Stachowiak (Bydgoszcz, Poland) for Carabidae, Dr. Marek Przewoźny (Poznań, Poland) for Hydrophilidae, Dr. Grzegorz Hebda (Opole, Poland) for Hemiptera, and Dr. Jarosław Kania (Wrocław, Poland) for Curculionidae. We also thank Guest Editor and three anonymous reviewers for their useful comments which greatly improved the article.

Funding information K. K. was financially supported by the Polish Ministry of Science and Higher Education (grant number 0420/1408/16).

Compliance with ethical standards All procedures were performed under permits from the General Directorate of Environmental Protection (permission no. WZP-WG.6401.02.4.2016.JRO).

Open Access This article is distributed under the terms of the Creative Commons Attribution 4.0 International License (http:// creativecommons.org/licenses/by/4.0/), which permits unrestricted use, distribution, and reproduction in any medium, provided you give appropriate credit to the original author(s) and the source, provide a link to the Creative Commons license, and indicate if changes were made.

\section{References}

Agasyan A, Avisi A, Tuniyev B, Crnobrnja-Isailovic J, Lymberakis P, Andrén C, Cogălniceanu D, Wilkinson J, Ananjeva N, Üzüm N, Orlov N, Podloucky R, Tuniyev S, Kaya U (2009) Bufo bufo. The IUCN Red List of Threatened Species 2009: e.T54596A11159939. https://doi.org/10.2305/IUCN.UK.2009.RLTS.T54596A11159939. en . Downloaded on 07 April 2018

Arntzen JW, Recuero E, Canestrelli D, Martinez-Solano I (2013) How complex is the Bufo bufo species group? Mol Phylogenet Evol 69: 1203-1208. https://doi.org/10.1016/j.ympev.2013.07.012

Aszalos L, Bogdan H, Kovacs ÉH, Peter VI (2005) Food composition of two Rana species on a forest habitat (Livada Plain, Romania). North-West J Zool 1:25-30 
Beebee TJC (2013) Effects of road mortality and mitigation measures on amphibian populations. Conserv Biol 27:657-668. https://doi.org/ 10.1111/cobi.12063

Bókony V, Üveges B, Ujhegyi N, Verebélyi V, Nemesházi E, Csíkvári O, Hettyey A (2018) Endocrine disruptors in breeding ponds and reproductive health of toad in agricultural, urban and natural landscapes. Sci Total Environ 634:1335-1345. https://doi.org/10.1016/ j.scitotenv.2018.03.363

Čađenović N, Stamenković S, Bjelić-Čabrilo O, Kralj S (2018) On the diet of recent metamorphs and adults of the common toad, Bufo bufo (Linnaeus, 1758) (Anura: Bufonidae). Herpetozoa 30:139-146

Caldwell JP (1996) The evolution of myrmecophagy and its correlates in poison frogs (family Dendrobatidae). J Zool 240:75-101. https:// doi.org/10.1111/j.1469-7998.1996.tb05487.x

Cogălniceanu D, Palmer MW, Ciubuc C (2000) Feeding in anuran communities on islands in the Danube floodplain. Amphibia-Reptilia 22: 1-19. https://doi.org/10.1163/156853801750096141

Colino-Rabanal VJ, Lizana M (2012) Herpetofauna and roads: a review. Basic Appl Herpetol 26:5-31

Crnobrnja-Isailović J, Ćurćić S, Stojadinović D, Tomašević-Kolarov N, Aleksić I, Tomanović Ž (2012) Diet composition and food preferences in adult common toads (Bufo bufo) (Amphibia: Anura: Bufonidae). J Herpetol 46:562-567. https://doi.org/10.1670/10-264

Davic RD, Welsh HH Jr (2004) On the ecological roles of salamanders. Annu Rev Ecol Evol Syst 35:405-434. https://doi.org/10.1146/ annurev.ecolsys.35.112202.130116

Denton JS, Beebee TJC (1994) The basis of niche separation during terrestrial life between two species of toads (Bufo bufo and Bufo calamita): competition or specialisation? Oecologia 97:390-393

Diaz-Paniagua C (1989) Larval diets of two anuran species, Pelodytes punctatus and Bufo bufo, in SW Spain. Amphibia-Reptilia 10:71-75

Dolmen D, Koksvik JI (1983) Food and feeding habits of Triturus vulgaris (L.) and T. cristatus (Laurenti) (Amphibia) in two bog tarns in Central Norway. Amphibia-Reptilia 4:17-24

Elzanowski A, Ciesiołkiewicz J, Kaczor M, Radwańska J, Urban R (2009) Amphibian road mortality in Europe: a meta-analysis with new data from Poland. Eur J Wildl Res 55:33-43. https://doi.org/10. 1007/s10344-008-0211-x

Gittins SP (1987) The diet of the common toad (Bufo bufo) around a pond in mid-Wales. Amphibia-Reptilia 8:13-17

Gossling J, Loesche WJ, Dan Ottoni L (1980) Passage of material through the gut of hibernating Rana pipiens (Amphibia, Anura, Ranidae). J Herpetol 14:407-409

Grace MK, Smith DJ, Noos RF (2017) Roadside abundance of anurans within a community correlates with reproductive investment. Front Ecol Evol 5:65. https://doi.org/10.3389/fevo.2017.00065

Guidali F, Scali T, Carettoni A (2000) Diet and trophic niche overlap of two ranid species in northern Italy. Ital J Zool 67:67-72. https://doi. org/10.1080/11250000009356297

Gunzburger SM (1999) Diet of red hills salamander Phaeognatus hubrichi. Copeia 2:523-525

Hels T, Buchwald E (2001) The effect of road kills on amphibian populations. Biol Conserv 99:331-340. https://doi.org/10.1016/S00063207(00)00215-9

Heusser H (1968) Die Lebensweise der Erdkröte, Bufo bufo (L.). Der Magenfullungsgrad in Abhangigkeit von Jagdstimmung und Wetter. Sitzungsber. Ges Naturf Freunde Berlin, pp. 148-156

Hocking DJ, Babbitt KJ (2014) Amphibian contributions to ecosystem services. Herpetol Conserv Biol 9:1-17

Houston WWK (1973) Food of common frog, Rana temporaria, on high moorland in northern England. J Zool (Lond) 171:153-165

Isacch JP, Barg M (2002) Are bufonid toads specialized ant feeders? A case test from the Argentinian flooding pampa. J Nat Hist 36:20052012. https://doi.org/10.1080/00222930110092153
Jiang S, Claussen DL (1993) The effects of temperature on food passage time through the digestive tract in Notophthalmus viridescens. $\mathrm{J}$ Herpetol 27:414-419

Jørgensen CB, Hede KE, Larsen LO (1978) Environmental control of annual ovarian cycle in the toad Bufo bufo bufo (L): role of temperature. In: Assenmacher I, Farner DS (eds) Environmental endocrinology. Springer, Berlin, pp 2-36

Kaczmarski M, Kolenda K, Rozenblut-Kościsty B, Sośnicka W (2016) Phalangeal bone anomalies in the European common toad Bufo bufo from polluted environments. Environ Sci Pollut Res 23:21940 21946. https://doi.org/10.1007/s11356-016-7297-6

Karg J, Mazur T (1969) Participation of amphibians in the natural reduction of the Colorado beetle (Leptinotarsa decemlineata Say). Ekologia Polska 27:515-532

Kolenda K, Kaczmarski M, Najbar A, Rozenblut-Kościsty B, Chmielewska M, Najbar B (2019) Road-killed toads as a noninvasive source to study age structure of spring migrating population. Eur J Wildl Res 65:5. https://doi.org/10.1007/s10344-018$1240-8$

Kopecký O, Vojar J, Šusta F, Rehák I (2011) Non-prey items in stomachs of alpine newts (Mesotriton alpestris, Laurenti). Pol J Ecol 59:631635

Kopecký O, Novák VJ, Šusta F (2016) Food composition of alpine newt (Ichthyosaura alpestris) in the post-hibernation terrestrial life stage. North-West J Zool 12:299-303

Kovács ÉH, Sas I, Covaciu-Marcov SD, Hartel T, Cupsa D, Groza M (2007) Seasonal variation in the diet of a population of Hyla arborea from Romania. Amphibia-Reptilia 28:485-491. https://doi.org/10. 1163/156853807782152534

Martel A, Fard MS, Van Rooij P, Jooris R, Boone F, Haesebrouck F, Van Rooij D, Pasmans F (2012) Road-killed common toads (Bufo bufo) in Flanders (Belgium) reveal low prevalence of ranaviruses and Batrachochytrium dendrobatidis. J Wildl Dis 48:835-839. https:// doi.org/10.7589/0090-3558-48.3.835

Mazerolle MJ (2004) Amphibian road mortality in response to nightly variation in traffic intensity. Herpetologica 60:45-53. https://doi.org/ 10.1655/02-109

Mollov IA, Boyadzhiev P (2009) A contribution to the knowledge of the trophic spectrum of the common toad (Bufo bufo L., 1758) (Amphibia: Anura) from Bulgaria. ZooNotes 4:1-4

Mollov IA, Stojanova AM (2010) Diet and trophic niche overlap of three toad species (Amphibia, Anura) from Poland. Biotechnol Biotechnol Equip 24:263-269

Orłowski G (2007) Spatial distribution and seasonal pattern in road mortality of the common toad Bufo bufo in an agricultural landscape of south-western Poland. Amphibia-Reptilia 28:25-31. https://doi.org/ 10.1163/156853807779799045

Orłowski G, Ciesiołkiewicz J, Kaczor M, Radwańska J, Żywicka A (2008) Species composition and habitat correlates of amphibian road-kills in different landscapes of south-western Poland. Pol J Ecol 56:659-671

Pesarakloo A, Rastegar-Pouyani N, Rastegar-Pouyani E, Najibzadeh M, Shakarami J, Kami HG, Shayestehfar A (2017) Feeding biology and food composition in Pelophylax ridibundus (Pallas 1771) in the Iranian plateau. Russ J Herpetol 24:91-98

Reading CJ, Clarke RT (1995) The effects of density, rainfall and environmental temperature on body condition and fecundity in the common toad, Bufo bufo. Oecologia 102:453-459

Santos SM, Carvalho F, Mira A (2011) How long do the dead survive on the road? Carcass persistence probability and implications for roadkill monitoring surveys. PLoS One 6:e25383. https://doi.org/10. 1371/journal.pone.0025383

Secor SM, Faulkner AC (2002) Effects of meal size, meal type, body temperature, and body size on the specific dynamic action of the marine toad, Bufo marinus. Physiol Biochem Zool 75:557-571. https://doi.org/10.1086/344493 
Smith M (1951) The British amphibians and reptiles. Collins, London

Solé M, Beckmann O, Pelz B, Kwet A, Engels W (2005) Stomach-flushing for diet analysis in anurans: an improved protocol evaluated in a case study in Araucaria forests, southern Brazil. Stud Neotrop Fauna E 40:23-28. https:// doi.org/10.1080/01650520400025704

Tennessen JB, Parks SE, Langkilde T (2014) Traffic noise causes physiological stress and impairs breeding migration behaviour in frogs. Conserv Physiol 2:1-8. https://doi.org/10.1093/conphys/cou032

Tinsley RC (1990) The influence of parasite infection on mating success in spadefoot toads, Scaphiopus couchii. Am Zool 30:313-324

Tinsley RC, Jackson HC (1988) Pulsed transmission of Pseudodiplorchis americanus (Monogenea) between desert hosts (Scaphiopus couchii). Parasitology 97:437-452

Tomašević N, Cvetković D, Aleksić I, Crnobrnja-Isailović J (2007) Effect of climatic conditions on post-hibernation body condition and reproductive traits of Bufo bufo. Arch Biol Sci 59:51-52. https://doi.org/ 10.2298/ABS070351PT

Tryjanowski P, Rybacki M, Sparks T (2003) Changes in spawning dates of common frogs and common toads in western Poland in 19782002. Ann Zool Fenn 40:459-464
Vences M, Glaw F, Böhme W (1998) Evolutionary correlates of microphagy in alkaloid-containing frogs (Amphibia: Anura). Zool Anz 236:217-230

Vignoli L, Luiselli L (2012) Dietary relationships among coexisting anuran amphibians: a worldwide quantitative review. Oecologia 169: 499-509. https://doi.org/10.1007/s00442-011-2204-9

Whiles MR, Lips KR, Pringle CM, Kilham SS, Bixby RJ, Brenes R, Connely S, Colon-Gaud JC, Hunte-Brown M, Huryn AD, Montgomery C, Peterson S (2006) The effects of amphibian population decline on the structure and function of neotropical stream ecosystems. Front Ecol Environ 4:27-34. https://doi.org/10.1890/ 1540-9295(2006)004[0027:TEOAPD]2.0.CO;2

Publisher's note Springer Nature remains neutral with regard to jurisdictional claims in published maps and institutional affiliations. 